\title{
The debate on treating subclinical hypothyroidism
}

Eng Loon Tng, MBBS, MRCP

\begin{abstract}
Subclinical hypothyroidism $(\mathrm{SCH})$ represents a mild or compensated form of primary hypothyroidism. The diagnosis of $\mathrm{SCH}$ is controversial, as its symptoms are non-specific and its biochemical diagnosis is arbitrary. The treatment of SCH was examined among non-pregnant adults, pregnant adults and children. In non-pregnant adults, treatment of $\mathrm{SCH}$ may prevent its progression to overt hypothyroidism, reduce the occurrence of coronary heart disease, and improve neuropsychiatric and musculoskeletal symptoms associated with hypothyroidism. These benefits are counteracted by cardiovascular, neuropsychiatric and musculoskeletal side effects. $\mathrm{SCH}$ is associated with adverse maternal and fetal outcomes that may improve with treatment. Treating $\mathrm{SCH}$ in children is safe and may improve growth. Importantly, the evidence in this field is largely from retrospective and prospective studies with design limitations, which precludes a conclusive recommendation for the treatment of $\mathrm{SCH}$.
\end{abstract}

Keywords: adolescents, children, overt hypothyroidism, pregnancy, subclinical hypothyroidism

\section{DEFINITION AND DIAGNOSIS OF SUBCLINICAL HYPOTHYROIDISM}

Subclinical hypothyroidism $(\mathrm{SCH})$ is a condition characterised by a normal free thyroxine $\left(\mathrm{FT}_{4}\right)$ level with an elevated thyrotropin (TSH) level. ${ }^{(1)}$ It represents a mild, ${ }^{(2,3)}$ compensated or preclinical form of primary hypothyroidism. ${ }^{(4)} \mathrm{SCH}$ may not be literally 'subclinical', as many individuals are symptomatic. ${ }^{(2,5)}$ However, its symptoms can be non-specific, and the elderly are commonly asymptomatic for $\mathrm{SCH} .{ }^{(6-9)}$ Consequently, some studies have recommended diagnosing $\mathrm{SCH}$ biochemically. ${ }^{(10)}$

The biochemical diagnosis of $\mathrm{SCH}$ is controversial, as most definitions are arbitrary. ${ }^{(1)}$ They are typically based on the condition that the TSH level exceeds the upper limit of the reference interval, ${ }^{(12)}$ although TSH assays differ between studies. ${ }^{(13)}$ Furthermore, Wartofsky and Dickey suspected that the reference interval of TSH may be lower than conventionally believed, ${ }^{(14)}$ as it varies with ethnicity, geographic region, gender and pregnancy status. ${ }^{(15)}$ TSH distribution curves also appeared to shift upward with increasing age. ${ }^{(16)}$ Lastly, obesity may be a confounder in TSH measurement, although observational studies were inconsistent in this area. ${ }^{(17-20)}$ Hence, the reference intervals for TSH based on age, gender, ethnicity, body mass index (BMI) and pregnancy status may need to be established before $\mathrm{SCH}$ can be clearly defined. $\mathrm{SCH}$ is commonly classified as mild when the TSH level is between $4.5 \mathrm{mIU} / \mathrm{L}$ and $10 \mathrm{mIU} / \mathrm{L}$, and severe when TSH levels exceed $10 \mathrm{mIU} / \mathrm{L}$ in non-pregnant adults. ${ }^{(4,21)}$

TSH levels fluctuate and its elevation may be transient. Thus, the thyroid function test (TFT) should be repeated prior to diagnosing $\mathrm{SCH}$, except in pregnant patients. ${ }^{(22,23)}$ Additionally, it is essential to exclude other causes of elevated TSH, including the nocturnal measurement of TFT, recovery phase of nonthyroidal illness, hypothyroid phase of thyroiditis, assay variability or interference, untreated hypocortisolism, ${ }^{(24,25)}$ pituitary thyrotrophoma, central hypothyroidism and TSH-receptor inactivation. ${ }^{(26)}$ This is a review on the treatment of $\mathrm{SCH}$ in three distinct populations: (a) non-pregnant adults; (b) pregnant adults; and (c) children.

\section{THE BENEFITS OF TREATING SUBCLINICAL HYPOTHYROIDISM IN NON-PREGNANT ADULTS}

Treating SCH may be beneficial in non-pregnant patients with: (a) progression to overt hypothyroidism $(\mathrm{OH})$; (b) coronary heart disease (CHD); (c) hypothyroid and neuropsychiatric symptoms; (d) musculoskeletal symptoms; and (e) other miscellaneous problems.

\section{Progression to overt hypothyroidism}

$\mathrm{SCH}$ can progress to $\mathrm{OH} .{ }^{(27)}$ In prospective studies, the cumulative incidence of $\mathrm{OH}$ ranges from $33 \%-55 \%$ within $10-20$ years in patients with $\mathrm{SCH} .{ }^{(28-30)}$ The annual rate of progression to $\mathrm{OH}$ in these patients ranges from $2 \%-6 \%$ within $5-6$ years. ${ }^{(31,32)}$ The risk factors for progression to $\mathrm{OH}$ include an initial TSH level exceeding $10 \mathrm{mIU} / \mathrm{L},{ }^{(29,33)}$ elevated titres of thyroid peroxidase antibodies (TPOAb) $)^{(31,34)}$ and the female gender. Conversely, $\mathrm{SCH}$ tends to resolve in TPOAb-negative subjects whose initial TSH levels are below $10 \mathrm{mIU} / \mathrm{L} .{ }^{(29,31,32)}$ It is uncertain if treating $\mathrm{SCH}$ prevents its progression to $\mathrm{OH}$.

\section{Clinical outcomes of coronary heart disease}

$\mathrm{SCH}$ is inconsistently associated with $\mathrm{CHD}$. Prospective studies showed a higher incidence of $\mathrm{CHD}$ in $\mathrm{SCH}$ patients. ${ }^{(35-37)} \mathrm{No}$ association was found when TSH levels were below $7 \mathrm{mIU} / \mathrm{L} .{ }^{(38)}$ The incidence of heart failure (HF) was also found to be higher in prospective cohort studies of $\mathrm{SCH}$ patients. ${ }^{(39)}$ A prospective cohort study by Rodondi et al demonstrated a positive correlation between TSH levels and HF risk, particularly when TSH levels exceeded $10 \mathrm{mIU} / \mathrm{L} .{ }^{(40)}$

Interestingly, the association between $\mathrm{SCH}, \mathrm{CHD}$ and $\mathrm{HF}$ may be influenced by age. A retrospective study revealed that $\mathrm{SCH}$ patients aged below 65 years had a greater prevalence of 
CHD and all-cause mortality; ${ }^{(37)}$ this was confirmed in metaanalyses of two prospective cohort studies. ${ }^{(41,42)}$ A prospective observational study ${ }^{(6)}$ and a subgroup analysis of the National Health and Nutrition Examination Survey (NHANES III) cohort ${ }^{(43)}$ also showed better $\mathrm{CHD}$ outcomes in elderly $\mathrm{SCH}$ patients. In contrast, three prospective studies, ${ }^{(44-46)}$ reported that $\mathrm{SCH}$ was not associated with $\mathrm{CHD}$. Selmer et al suggested that $\mathrm{SCH}$ may protect patients against atrial fibrillation. ${ }^{(47)} \mathrm{A}$ retrospective cohort study by Razvi et al showed that patients between 40 and 70 years of age who were treated for $\mathrm{SCH}$ had lower hazard ratios for $\mathrm{CHD}$ events and all-cause mortality; no benefit was seen in patients beyond the age of 70 years. ${ }^{(48)}$ Additionally, incident CHD, CHD mortality and the number of $\mathrm{HF}$ events were lower in the treatment groups in two prospective cohort studies. ${ }^{(35,40)}$ Unfortunately, the Cochrane review ${ }^{(49)}$ did not evaluate the effects of treatment on CHD outcomes.

\section{Surrogate measures of coronary heart disease risk}

$\mathrm{SCH}$ is associated with surrogate measures of CHD risk, including echocardiographic measures of cardiac function, endothelial function, blood pressure (BP), lipid levels and various metabolic parameters. $\mathrm{SCH}$ was also associated with depressed systolic and diastolic ventricular function on echocardiography. ${ }^{(9)} \mathrm{A}$ placebo-controlled study by Monzani et al ${ }^{(50)}$ and the Cochrane review ${ }^{(49)}$ confirmed these findings, which improved with treatment. Reduced vasodilatation, ${ }^{(51)}$ increased systemic vascular resistance and arterial stiffness ${ }^{(52)}$ in $\mathrm{SCH}$ patients were reported in a randomised controlled trial (RCT) by Razvi et al. ${ }^{(53)}$ Another RCT demonstrated increased carotid intima-media thickness (CIMT) in $\mathrm{SCH}$ patients. ${ }^{(54)}$ Furthermore, treatment of $\mathrm{SCH}$ was shown to improve endothelial function, ${ }^{(53)} \mathrm{CIMT}^{(54,55)}$ and homocysteinaemia. ${ }^{(56)}$

Hypertension was more common in $\mathrm{SCH}$ patients in two cross-sectional ${ }^{(57,58)}$ and one prospective study. ${ }^{(35)}$ Three studies showed no reduction of BP with treatment, ${ }^{(53,54,59)}$ with the exception of Adrees et al's interventional trial. ${ }^{(56)}$ Two studies, ${ }^{(5,35)}$ which lacked statistical adjustment for age, and Monzani et al's $\mathrm{RCT}^{(50)}$ reported that $\mathrm{SCH}$ patients had elevated total cholesterol (TC) and low-density lipoprotein cholesterol (LDL-C) levels. The literature showed reduced TC and LDL-C levels with treatment of $\mathrm{SCH} .{ }^{(53,54,56,60,61)}$ Furthermore, in prospective interventional studies, ${ }^{(62,63)}$ atherogenic lipid profiles improved with treatment of $\mathrm{SCH}$, particularly in patients with severe dyslipidaemia and $\mathrm{SCH}$. On the other hand, some RCTs showed no benefits for lipid profiles with treatment of $\mathrm{SCH} .{ }^{(59,64-67)}$ Finally, the Cochrane review and a systematic review reported a decreasing trend in lipid parameters with treatment of $\mathrm{SCH}^{(49,68)}$ In the literature, $\mathrm{SCH}$ was not associated with weight gain and metabolic syndrome. ${ }^{(17,69,70)}$ Treating SCH did not reduce patient weight in many studies. ${ }^{(53,54,59,63,67)}$

\section{Hypothyroid and neuropsychiatric symptoms}

$\mathrm{SCH}$ has been associated with mood disorders, a reduced quality of life ${ }^{(53,71)}$ and treatment failure in depression. ${ }^{(72)}$ However, this association was not seen in two cross-sectional studies ${ }^{(73,74)}$ and one prospective cohort study. ${ }^{(75)}$ Most interventional trials showed no improvement in hypothyroid symptoms, quality of life and neuropsychiatric symptoms with treatment of $\mathrm{SCH} .{ }^{(53,67,76,77)}$ Meier et al showed improvement in mood, cognition and hypothyroid symptoms only when TSH levels exceeded $10 \mathrm{mIU} / \mathrm{L} .{ }^{(60)}$ Other interventional studies showed modest improvements in mood, ${ }^{(78)}$ memory ${ }^{(66)}$ and hypothyroid symptoms. ${ }^{(64)}$ However, these were small RCTs of short durations. The Cochrane review concluded that treating $\mathrm{SCH}$ did not benefit mood, quality of life and hypothyroid symptoms. ${ }^{(49)}$

\section{Musculoskeletal symptoms}

Reuters et al reported that weakness and myalgia were more prevalent in $\mathrm{SCH} .{ }^{(79)}$ Brennan et al showed that $\mathrm{SCH}$ was also associated with reduced muscular strength. ${ }^{(80)}$ However, two prospective cohort studies, by Simonsick et al and Virgini et al, showed no associations between $\mathrm{SCH}$ and musculoskeletal symptoms. ${ }^{(8,81)}$ Furthermore, physical function appeared to be better in elderly subjects with $\mathrm{SCH} .{ }^{(9)}$ There were conflicting reports on fracture rates from prospective cohort studies by Lee et al and Svare et al. ${ }^{(82,83)}$ Brennan et $\mathrm{al}^{(80)}$ showed improvement in strength measurements, while Mainenti et $\mathrm{al}^{(84)}$ showed improvement in cardiopulmonary performance with treatment.

\section{Other manifestations of subclinical hypothyroidism}

A prospective trial associated impaired gastric motility with $\mathrm{SCH}$ in premenopausal women. ${ }^{(85)} \mathrm{A}$ cross-sectional study by Chung et al showed a linear relationship between non-alcoholic fatty liver disease and $\mathrm{SCH} .{ }^{(86)} \mathrm{RCT}$ s by Cinemre et al and Ravanbod et al showed that the treatment of $\mathrm{SCH}$ led to better correction of iron deficiency anaemia, ${ }^{(87,88)}$ while that by ChristCrain et al did not. ${ }^{(89)}$ A Korean prospective interventional study by Shin et al found that treating $\mathrm{SCH}$ slowed the progression of chronic kidney disease. ${ }^{(90)}$ However, these trials were small and the reported benefits require replication in larger trials.

\section{RISKS OF TREATING SUBCLINICAL HYPOTHYROIDISM IN NON-PREGNANT ADULTS}

Overtreatment of $\mathrm{SCH}$ can cause complications and symptoms of thyrotoxicosis ${ }^{(27)}$ have been reported. Nervousness and anxiety were reported by Nyström et $\mathrm{al}^{(65)}$ and Kong et al. ${ }^{(67)}$ Some subjects "felt worse" following treatment in a placebocontrolled study by Cooper et al. ${ }^{(64)}$ Tachyarrhythmias and angina pectoris were also reported by Nyström et $\mathrm{al}^{(65)}$ and Jaeschke et al. ${ }^{(66)}$ Low bone mass and fractures are also potential complications of treatment. ${ }^{(91)}$ Conversely, many RCTs demonstrated the safety of thyroxine for the treatment of $\mathrm{SCH}$, as no participants reported adverse effects, required dose reduction or withdrew from the studies. ${ }^{(53,59,76,92)}$ The Cochrane review ${ }^{(49)}$ noted that only four studies reported adverse outcomes with the treatment of $\mathrm{SCH}$, and none showed significant associations between treatment and adverse outcomes. However, these studies were poorly designed and underpowered. As evidence is lacking, the United States Preventive Services Task Force ${ }^{(1)}$ 
and the Cochrane review made no specific recommendations in this regard.

\section{SUBCLINICAL HYPOTHYROIDISM IN PREGNANCY}

The diagnosis of $\mathrm{SCH}$ differs slightly in pregnant patients. Firstly, the symptoms of pregnancy mimic hypothyroidism, ${ }^{(5)}$ mandating the biochemical diagnosis of $\mathrm{SCH}$. Secondly, gestational changes in the hypothalamic-pituitary-thyroid axis interfere with the measurement of $\mathrm{FT}_{4}$ by conventional assays. ${ }^{(93,94)}$ Consequently, an emphasis is placed on TSH measurement, for which guidelines recommend establishing local trimester-specific reference intervals. ${ }^{(95,96)}$ Lastly, the diagnostic threshold for $\mathrm{SCH}$ in pregnancy differs from that in non-pregnant adults. Using trimester-specific reference intervals, the American Thyroid Association (ATA) and Endocrine Society ${ }^{(96)}$ recommend the following thresholds for TSH level: (a) between 0.1-2.5 mIU/L in the first trimester; (b) between $0.2-3.0 \mathrm{mIU} / \mathrm{L}$ in the second trimester; and (c) between $0.3-3.5 \mathrm{mlU} / \mathrm{L}$ in the third trimester.

\section{Maternal outcomes}

It has been debated whether $\mathrm{SCH}$ leads to adverse maternal outcomes. A prospective cohort study by Casey et al on 25,000 pregnancies showed a higher incidence of placental abruption and preterm delivery in patients with $\mathrm{SCH} .{ }^{(97)}$ An association with miscarriages was demonstrated in cohort studies by Benhadi et al and Allan et $\mathrm{al}^{(98,99)}$ and prospective trials by Negro et al and Liu et al; ${ }^{(100,101)}$ Wilson et al reported significantly higher preeclampsia rates in the $\mathrm{SCH}$ cohort. ${ }^{(102)} \mathrm{A}$ small cohort study by Leung et al, involving 68 pregnancies, showed an association between $\mathrm{SCH}$ and gestational hypertension (including pregnancyinduced hypertension, preeclampsia, and eclampsia). ${ }^{(103)}$ These adverse maternal outcomes were reaffirmed in two meta-analyses by Reid et al and Thangaratinam et al. ${ }^{(104,105)}$ However, ClearyGoldman et al did not find an association between $\mathrm{SCH}$ and maternal adverse outcomes in their prospective cohort study involving 10,000 pregnancies. ${ }^{(106)}$ The adverse outcomes that were measured included preterm labour, macrosomia, gestational diabetes mellitus and preterm premature rupture of membranes. ${ }^{(106)}$

\section{Fetal outcomes}

The adverse outcomes of $\mathrm{SCH}$ in the fetus include perinatal morbidity and mortality, as well as subsequent neurologic and psychomotor delays. Saki et al's study on 600 pregnancies associated $\mathrm{SCH}$ with intrauterine growth retardation and low Apgar scores. ${ }^{(107)}$ A cohort study on 2,500 pregnancies found a significantly higher prevalence of neonatal respiratory distress and intensive care unit admissions. ${ }^{(98)}$ Smit et al ${ }^{(108)}$ showed delayed neurologic development in children born to mothers with $\mathrm{SCH}$. However, this study only included 20 subjects, and psychomotor testing was conducted variably from the ages of 6-24 months. ${ }^{(108)}$ Subsequently, Li et al confirmed poorer intellectual and motor development in children aged 25-30 months who were born to mothers with $\mathrm{SCH}$ during pregnancy. ${ }^{(109)}$ Additionally, Haddow et al demonstrated lower intelligence quotient (IQ) scores in the offspring (aged 7-9 years) of SCH mothers in a cohort study involving 25,000 subjects. ${ }^{(10)}$ Worryingly, Ajmani et al's study on 400 women reported adverse maternal and fetal outcomes in $\mathrm{SCH} .{ }^{(111)}$ Conversely, Lazarus et al showed no cognitive impairment in children whose mothers had $\mathrm{SCH}$ during pregnancy. ${ }^{(112)}$ However, this study was limited, as it measured cognition using different IQ tests at different ages; furthermore, different TSH assays were used between the centres.

\section{Controversy over treatment during pregnancy}

The arguments for treating $\mathrm{SCH}$ during pregnancy include a reduction in obstetric and neonatal complications, as seen in the RCT by Negro et al, ${ }^{(113)}$ and an improvement in miscarriage and live birth rates in women undergoing assisted reproductive techniques. ${ }^{(14)}$ On the other hand, the RCT by Lazarus et al showed no cognitive benefits in the offspring of mothers who were treated. ${ }^{(112)}$ In light of the conflicting and limited evidence, the Cochrane review did not reach a conclusion on this issue. ${ }^{(49)}$ The ATA recommended treating SCH if TPOAb titres are elevated ${ }^{(95)}$ and made no recommendations for TPOAb-negative subjects. However, it opined that treatment is reasonable in a woman at risk for $\mathrm{SCH}$ complications. Arguably, treatment of $\mathrm{SCH}$ in pregnant women may be proposed, as the associated cost and risks are low. A clear discussion with the patient, stating the pros and cons of treatment (and lack of treatment), is advised.

\section{SUBCLINICAL HYPOTHYROIDISM IN CHILDREN AND ADOLESCENTS}

The definition and adverse outcomes of $\mathrm{SCH}$ in children and adolescents are similar to those in adults. ${ }^{(4)}$ Among children and adolescents in the NHANES III cohort, $1.7 \%$ had $\mathrm{SCH}^{(115)}$ while other studies report a prevalence up to $9.5 \% .{ }^{(116)}$

\section{Progression to overt hypothyroidism}

Based on prospective studies, the majority of children and adolescents with $\mathrm{SCH}$ do not progress to $\mathrm{OH} .{ }^{(117)}$ In the prospective studies conducted on children with goitre ${ }^{(118)}$ and autoimmune thyroiditis, ${ }^{(119,120)}$ between $5.6 \%-50 \%$ of patients progressed to $\mathrm{OH}$. Wasniewska et al studied children with no identifiable aetiologies for their $\mathrm{SCH} ; 20.4 \%$ of them progressed to $\mathrm{OH}^{(121)}$

Several factors may predict the progression of $\mathrm{SCH}$ to $\mathrm{OH}$. In a retrospective analysis of 120,000 children, Lazar et al found a greater occurrence of $\mathrm{OH}$ in children with initial TSH levels above $7.5 \mathrm{mIU} / \mathrm{L}$ and those who were female. ${ }^{(122)}$ Radetti et al found that on initial presentation, goitre and elevated antithyroglobulin antibody titres predicted the progression to $\mathrm{OH}$; on followup, rising TPOAb titres and TSH levels were also found to be risk factors for progression. ${ }^{(123)}$ Lastly, Wasniewska et al found an association between prepubertal status at diagnosis and progression to $\mathrm{OH} .{ }^{(121)}$

\section{Skeletal development}

Two studies by Cerbone et $\mathrm{al}^{(124)}$ and Di Mase et $\mathrm{al}^{(125)}$ reported the lack of impact of $\mathrm{SCH}$ on skeletal growth and maturation in children. Cerbone et al found no significant difference in the 
growth, bone maturation and $\mathrm{BMI}$ of 36 children with $\mathrm{SCH}$ who were matched with controls. ${ }^{(124)}$ Similarly, Di Mase et al reported no differences in the lumbar spine bone density and phalangeal quantitative ultrasonography in 25 children with $\mathrm{SCH}^{.125)}$

\section{Intellectual development and puberty}

SCH does not appear to impact cognitive development in children. Cerbone et al described no relationship between TSH levels and IQ or behaviour in children with $\mathrm{SCH}^{(124)}$ Verbal fluency and encoding test scores were also not affected by $\mathrm{SCH}$ in another case-control study by Ergür et al. ${ }^{(126)}$ Pubertal delay was not found to be associated with $\mathrm{SCH}$ by Cerbone et al and Rapa et al. ${ }^{(124,127)}$

\section{Cardiovascular risk factors}

$\mathrm{SCH}$ was associated with hypertension in children and adolescents in two cross-sectional studies by Chen et al and Ittermann et al. ${ }^{(128,129)}$ Furthermore, triglyceride levels, homocysteine levels and waist-to-hip ratios were higher in children with $\mathrm{SCH}$ compared to controls in another crosssectional study by Cerbone et al, which also found that highdensity lipoprotein cholesterol was lower in SCH patients. ${ }^{(130)}$

\section{Migraine}

The association between $\mathrm{SCH}$ and migraines is controversial. Small cross-sectional studies by Fallah et al and Ekici et al offered conflicting results in this regard. ${ }^{(131,132)}$

\section{Treating children and adolescents}

In children and adolescents, the treatment of $\mathrm{SCH}$ does not appear to confer benefits. A retrospective study reported improvement in growth velocity following thyroxine therapy. However, this prospective study was conducted among type 1 diabetes mellitus patients. An observational study by Aijaz et al, conducted over eight weeks, reported no effects on the neuropsychological function of children, ${ }^{(133)}$ although this study had methodological flaws. Treatment does not prevent progression to $\mathrm{OH} .{ }^{(134)}$ In their review, De Luca et al found no improvement in growth and bone maturation, $\mathrm{BMI}$ and cognitive function with treatment of $\mathrm{SCH} .{ }^{(135)}$ Cetinkaya et $\mathrm{al}^{(136)}$ reported no treatment side effects. However, in a prospective study by Eyal et al that was conducted in the United States, $12.5 \%$ of children were over-treated. ${ }^{(137)}$ Rother et al and Svensson et al reported a reduction in goitre size with treatment. ${ }^{(138,139)}$

As the evidence is limited, the ATA recommends against treating $\mathrm{SCH}$ in children with a TSH level of $5-10 \mathrm{mlU} / \mathrm{L}$. It recommends treating $\mathrm{SCH}$ in children when: (a) the $\mathrm{TSH}$ level exceeds $10 \mathrm{mIU} / \mathrm{L}$; (b) the child is symptomatic; or (c) the child is at risk for $\mathrm{OH}$. Additionally, treatment may be considered if a goitre is present, the child is TPOAb-positive or when growth is compromised. ${ }^{(140)}$

\section{CONCLUSION}

The treatment of $\mathrm{SCH}$ is highly controversial. These controversies may be clarified when the results of the Thyroid Hormone Replacement for Subclinical Hypothyroidism study, an ongoing multi-centre European RCT, are published. For now, the treatment decision needs to be individualised. Treatment may be considered if: (a) symptoms are present; (b) there is a goitre; (c) there is risk of progression to $\mathrm{OH}$; (d) there are risks of $\mathrm{CHD}$, particularly in patients younger than 70 years of age; or (e) TSH levels exceed $10 \mathrm{mIU} / \mathrm{L}$. Furthermore, SCH should be identified accurately (if possible) and treated adequately in pregnant women, lactating mothers, neonates and children. This is because unidentified and untreated $\mathrm{SCH}$ in these populations may lead to dire consequences.

\section{REFERENCES}

1. Surks MI, Ortiz E, Daniels GH, et al. Subclinical thyroid disease: scientific review and guidelines for diagnosis and management. JAMA 2004; 291:228-38.

2. Rugge JB, Bougatsos C, Chou R. Screening and treatment of thyroid dysfunction: an evidence review for the U.S. Preventive Services Task Force. Ann Intern Med 2015; 162:35-45.

3. Cooper DS. Clinical practice. Subclinical hypothyroidism. N Engl J Med $2001 ; 345: 260-5$.

4. McDermott MT, Ridgway EC. Subclinical hypothyroidism is mild thyroid failure and should be treated. J Clin Endocrinol Metab 2001; 86:4585-90.

5. Canaris GJ, Manowitz NR, Mayor G, Ridgway EC. The Colorado thyroid disease prevalence study. Arch Intern Med 2000; 160:526-34.

6. Gussekloo J, van Exel E, de Craen AJ, et al. Thyroid status, disability and cognitive function, and survival in old age. JAMA 2004; 292:2591-9.

7. Lindeman RD, Schade DS, LaRue A, et al. Subclinical hypothyroidism in a biethnic, urban community. J Am Geriatr Soc 1999; 47:703-9.

8. Simonsick EM, Newman AB, Ferrucci L, et al. Subclinical hypothyroidism and functional mobility in older adults. Arch Intern Med 2009; 169:2011-7.

9. Biondi B. Cardiovascular effects of mild hypothyroidism. Thyroid 2007; 17:625-30.

10. Garg A, Vanderpump MP. Subclinical thyroid disease. Br Med Bull 2013; 107:101-16.

11. Helfand M. Screening for thyroid disease [online]. In: U.S. Preventive Services Task Force Evidence Syntheses, formerly Systematic Evidence Reviews. Rockville, MD: Agency for Healthcare Research and Quality, 2004.

12. Waise A, Price HC. The upper limit of the reference range for thyroidstimulating hormone should not be confused with a cut-off to define subclinical hypothyroidism. Ann Clin Biochem 2009; 46(Pt 2):93-8.

13. Biondi B, Cooper DS. The clinical significance of subclinical thyroid dysfunction. Endocr Rev 2008; 29:76-131.

14. Wartofsky L, Dickey RA. The evidence for a narrower thyrotropin reference range is compelling. J Clin Endocrinol Metab 2005; 90:5483-8.

15. Surks MI, Boucai L. Age- and race-based serum thyrotropin reference limits. J Clin Endocrinol Metab 2010; 95:496-502.

16. Surks MI, Hollowell JG. Age-specific distribution of serum thyrotropin and antithyroid antibodies in the US population: implications for the prevalence of subclinical hypothyroidism. J Clin Endocrinol Metab 2007; 92:4575-82.

17. Knudsen N, Laurberg P, Rasmussen LB, et al. Small differences in thyroid function may be important for body mass index and the occurrence of obesity in the population. J Clin Endocrinol Metab 2005; 90:4019-24.

18. Nyrnes A, Jorde R, Sundsfjord J. Serum TSH is positively associated with BMI. Int J Obes (Lond) 2006; 30:100-5.

19. Fox CS, Pencina MJ, D'Agostino RB, et al. Relations of thyroid function to body weight: cross-sectional and longitudinal observations in a community-based sample. Arch Intern Med 2008; 168:587-92.

20. Manji N, Boelaert K, Sheppard MC, et al. Lack of association between serum TSH or free T4 and body mass index in euthyroid subjects. Clin Endocrinol (Oxf) 2006; 64:125-8.

21. Surks MI, Goswami G, Daniels $\mathrm{GH}$. The thyrotropin reference range should remain unchanged. J Clin Endocrinol Metab 2005; 90:5489-96.

22. Garber JR, Cobin RH, Gharib H, et al; American Association Of Clinical Endocrinologists And American Thyroid Association Taskforce On Hypothyroidism In Adults. Clinical practice guidelines for hypothyroidism in adults: cosponsored by the American Association of Clinical Endocrinologists and the American Thyroid Association. Thyroid 2012; 
22:1200-35. Erratum in: Thyroid 2013; 23:251.

23. Cooper DS, Biondi B. Subclinical thyroid disease. Lancet 2012; 379:1142-54

24. Stryker TD, Molitch ME. Reversible hyperthyrotropinemia, hyperthyroxinemia, and hyperprolactinemia due to adrenal insufficiency. Am J Med 1985; 79:271-6.

25. Abdullatif HD, Ashraf AP. Reversible subclinical hypothyroidism in the presence of adrenal insufficiency. Endocr Pract 2006; 12:572.

26. Jordan N, Williams N, Gregory JW, et al. The W546X mutation of the thyrotropin receptor gene: potential major contributor to thyroid dysfunction in a Caucasian population. J Clin Endocrinol Metab 2003; 88:1002-5.

27. Helfand M, U.S. Preventive Services Task Force. Screening for subclinical thyroid dysfunction in nonpregnant adults: a summary of the evidence for the U.S. Preventive Services Task Force. Ann Intern Med 2004; 140:128-41

28. Huber G, Staub JJ, Meier C, et al. Prospective study of the spontaneous course of subclinical hypothyroidism: prognostic value of thyrotropin thyroid reserve, and thyroid antibodies. J Clin Endocrinol Metab 2002; 87:3221-6.

29. Vanderpump MP, Tunbridge WM, French JM, et al. The incidence of thyroid disorders in the community: a twenty-year follow-up of the Whickham Survey. Clin Endocrinol (Oxf) 1995; 43:55-68.

30. Kabadi UM. 'Subclinical hypothyroidism'. Natural course of the syndrome during a prolonged follow-up study. Arch Intern Med 1993; 153:957-61.

31. Meyerovitch J, Rotman-Pikielny $P$, Sherf $M$, et al. Serum thyrotropin measurements in the community: five-year follow-up in a large network of primary care physicians. Arch Intern Med 2007; 167:1533-8.

32. Somwaru LL, Rariy CM, Arnold AM, Cappola AR. The natural history of subclinical hypothyroidism in the elderly: the cardiovascular health study. J Clin Endocrinol Metab 2012; 97:1962-9.

33. Díez JJ, Iglesias P, Burman KD. Spontaneous normalization of thyrotropin concentrations in patients with subclinical hypothyroidism. J Clin Endocrinol Metab 2005; 90:4124-7.

34. Hollowell JG, Staehling NW, Flanders WD, et al. Serum TSH, T(4), and thyroid antibodies in the United States population (1988 to 1994): National Health and Nutrition Examination Survey (NHANES III). J Clin Endocrinol Metab 2002; 87:489-99.

35. Razvi S, Weaver JU, Vanderpump MP, Pearce SH. The incidence of ischemic heart disease and mortality in people with subclinica hypothyroidism: reanalysis of the Whickham Survey cohort. J Clin Endocrinol Metab 2010; 95:1734-40.

36. Walsh JP, Bremner AP, Bulsara MK, et al. Subclinical thyroid dysfunction as a risk factor for cardiovascular disease. Arch Intern Med 2005; 165:2467-72

37. McQuade C, Skugor M, Brennan DM, et al. Hypothyroidism and moderate subclinical hypothyroidism are associated with increased all-cause mortality independent of coronary heart disease risk factors: a PreCIS database study. Thyroid 2011; 21:837-43

38. Rodondi N, den Elzen WP, Bauer DC, et al; Thyroid Studies Collaboration. Subclinical hypothyroidism and the risk of coronary heart disease and mortality. JAMA 2010; 304:1365-74

39. Gencer B, Collet TH, Virgini V, et al; Thyroid Studies Collaboration. Subclinical thyroid dysfunction and the risk of heart failure events: an individual participant data analysis from 6 prospective cohorts. Circulation 2012; 126:1040-9.

40. Rodondi N, Bauer DC, Cappola AR, et al. Subclinical thyroid dysfunction, cardiac function, and the risk of heart failure. The Cardiovascular Health study. J Am Coll Cardiol 2008; 52:1152-9.

41. Ochs N, Auer R, Bauer DC, et al. Meta-analysis: subclinical thyroid dysfunction and the risk for coronary heart disease and mortality. Ann Intern Med 2008; 148:832-45.

42. Razvi S, Shakoor A, Vanderpump M, Weaver JU, Pearce SH. The influence of age on the relationship between subclinical hypothyroidism and ischemic heart disease: a metaanalysis. J Clin Endocrinol Metab 2008; 93:2998-3007.

43. Atzmon G, Barzilai N, Hollowell JG, Surks MI, Gabriely I. Extreme longevity is associated with increased serum thyrotropin. J Clin Endocrino Metab 2009: 94:1251-4

44. Cappola AR, Fried LP, Arnold AM, et al. Thyroid status, cardiovascular risk, and mortality in older adults. JAMA 2006; 295:1033-41.

45. Sgarbi JA, Matsumura LK, Kasamatsu TS, Ferreira SR, Maciel RM Subclinical thyroid dysfunctions are independent risk factors for mortality in a 7.5-year follow-up: the Japanese-Brazilian thyroid study. Eur Endocrinol 2010; 162:569-77.
46. Boekholdt SM, Titan SM, Wiersinga WM, et al. Initial thyroid status and cardiovascular risk factors: the EPIC-Norfolk prospective population study. Clin Endocrinol (Oxf) 2010; 72:404-10.

47. Selmer C, Olesen JB, Hansen ML, et al. The spectrum of thyroid disease and risk of new onset atrial fibrillation: a large population cohort study. BMJ 2012; 345:e7895.

48. Razvi S, Weaver JU, Butler TJ, Pearce SH. Levothyroxine treatment of subclinical hypothyroidism, fatal and nonfatal cardiovascular events, and mortality. Arch Intern Med 2012; 172:811-7.

49. Villar HC, Saconato H, Valente O, Atallah AN. Thyroid hormone replacement for subclinical hypothyroidism. Cochrane Database Syst Rev 2007; CD003419.

50. Monzani F, Di Bello V, Caraccio N, et al. Effect of levothyroxine on cardiac function and structure in subclinical hypothyroidism: a double blind, placebo-controlled study. J Clin Endocrinol Metab 2001; $86: 1110-5$

51. Taddei S, Caraccio N, Virdis A, et al. Impaired endothelium-dependent vasodilatation in subclinical hypothyroidism: beneficial effect of levothyroxine therapy. J Clin Endocrinol Metab 2003; 88:3731-7.

52. Owen PJ, Sabit R, Lazarus JH. Thyroid disease and vascular function. Thyroid 2007; 17:519-24.

53. Razvi S, Ingoe L, Keeka G, et al. The beneficial effect of L-thyroxine on cardiovascular risk factors, endothelial function, and quality of life in subclinical hypothyroidism: randomized, crossover trial. J Clin Endocrinol Metab 2007; 92:1715-23

54. Monzani F, Caraccio N, Kozàkowà M, et al. Effect of levothyroxine replacement on lipid profile and intima-media thickness in subclinical hypothyroidism: a double-blind, placebo- controlled study. J Clin Endocrinol Metab 2004; 89:2099-106.

55. Dardano A, Monzani F. Thyroid function and carotid artery intima-media thickness. Circ J 2007; 71:993.

56. Adrees M, Gibney J, El-Saeity N, Boran G. Effects of 18 months of L-T4 replacement in women with subclinical hypothyroidism. Clin Endocrinol (Oxf) 2009; 71:298-303

57. Liu D, Jiang F, Shan Z, et al. A cross-sectional survey of relationship between serum TSH level and blood pressure. J Hum Hypertens 2010; 24:134-8.

58. Luboshitzky R, Aviv A, Herer P, Lavie L. Risk factors for cardiovascular disease in women with subclinical hypothyroidism. Thyroid 2002; 12:421-5.

59. Nagasaki T, Inaba M, Yamada S, et al. Decrease of brachial-ankle pulse wave velocity in female subclinical hypothyroid patients during normalization of thyroid function: a double-blind, placebo-controlled study. Eur J Endocrinol 2009; 160:409-15.

60. Meier C, Staub JJ, Roth CB, et al. TSH-controlled L-thyroxine therapy reduces cholesterol levels and clinical symptoms in subclinical hypothyroidism: a double blind, placebo-controlled trial (Basel Thyroid Study). J Clin Endocrinol Metab 2001; 86:4860-6.

61. Caraccio N, Ferrannini E, Monzani F. Lipoprotein profile in subclinical hypothyroidism: response to levothyroxine replacement, a randomized placebo-controlled study. J Clin Endocrinol Metab 2002; 87:1533-8.

62. Serter R, Demirbas B, Korukluoglu B, et al. The effect of L-thyroxine replacement therapy on lipid based cardiovascular risk in subclinical hypothyroidism. J Endocrinol Invest 2004; 27:897-903.

63. Iqbal A, Jorde R, Figenschau Y. Serum lipid levels in relation to serum thyroid-stimulating hormone and the effect of thyroxine treatment on serum lipid levels in subjects with subclinical hypothyroidism: the Tromsø Study. J Intern Med 2006; 260:53-61.

64. Cooper DS, Halpern R, Wood LC, Levin AA, Ridgway EC. L-Thyroxine therapy in subclinical hypothyroidism. A double-blind, placebocontrolled trial. Ann Intern Med 1984; 101:18-24

65. Nyström E, Caidahl K, Fager G, et al. A double-blind cross-over 12-month study of L-thyroxine treatment of women with 'subclinical' hypothyroidism. Clin Endocrinol (Oxf) 1988; 29:63-75.

66. Jaeschke R, Guyatt G, Gerstein H, et al. Does treatment with L-thyroxine influence health status in middle-aged and older adults with subclinical hypothyroidism? J Gen Intern Med 1996; 11:744-9.

67. Kong WM, Sheikh MH, Lumb PJ, et al. A 6-month randomized trial of thyroxine treatment in women with mild subclinical hypothyroidism. Am J Med 2002; 112:348-54

68. Danese MD, Ladenson PW, Meinert CL, Powe NR. Clinical review 115 effect of thyroxine therapy on serum lipoproteins in patients with mild thyroid failure: a quantitative review of the literature. J Clin Endocrinol Metab 2000; 85:2993-3001.

69. Garin MC, Arnold AM, Lee JS, Tracy RP, Cappola AR. Subclinical 
hypothyroidism, weight change, and body composition in the elderly: the Cardiovascular Health Study. J Clin Endocrinol Metab 2014; 99:1220-6.

70. Waring AC, Rodondi N, Harrison S, et al; Health, Ageing, and Body Composition (Health $\mathrm{ABC}$ ) Study. Thyroid function and prevalent and incident metabolic syndrome in older adults: the Health, Ageing and Body Composition Study. Clin Endocrinol (Oxf) 2012; 76:911-8.

71. Monzani F, Del Guerra P, Caraccio N, et al. Subclinical hypothyroidism: neurobehavioral features and beneficial effect of L-thyroxine treatment. Clin Investig 1993; 71:367-71.

72. Pae CU, Mandelli L, Han C, et al. Thyroid hormones affect recovery from depression during antidepressant treatment. Psychiatry Clin Neurosci 2009; 63:305-13.

73. Roberts LM, Pattison H, Roalfe A, et al. Is subclinical thyroid dysfunction in the elderly associated with depression or cognitive dysfunction? Ann Intern Med 2006; 145:573-81.

74. Parsaik AK, Singh B, Roberts RO, et al. Hypothyroidism and risk of mild cognitive impairment in elderly persons: a population-based study. JAMA Neurol 2014; 71:201-7.

75. de Jongh RT, Lips $\mathrm{P}$, van Schoor NM, et al. Endogenous subclinical thyroid disorders, physical and cognitive function, depression, and mortality in older individuals. Eur J Endocrinol 2011; 165:545-54.

76. Parle J, Roberts L, Wilson S, et al. A randomized controlled trial of the effect of thyroxine replacement on cognitive function in community-living elderly subjects with subclinical hypothyroidism: the Birmingham Elderly Thyroid study. J Clin Endocrinol Metab 2010; 95:3623-32.

77. Jorde R, Waterloo K, Storhaug H, et al. Neuropsychological function and symptoms in subjects with subclinical hypothyroidism and the effect of thyroxine treatment. J Clin Endocrinol Metab 2006; 91:145-53.

78. Correia N, Mullally S, Cooke G, et al. Evidence for a specific defect in hippocampal memory in overt and subclinical hypothyroidism. J Clin Endocrinol Metab 2009; 94:3789-97.

79. Reuters VS, Teixeira Pde F, Vigário PS, et al. Functional capacity and muscular abnormalities in subclinical hypothyroidism. Am J Med Sci 2009; 338:259-63

80. Brennan MD, Powell C, Kaufman KR, et al. The impact of overt and subclinical hyperthyroidism on skeletal muscle. Thyroid 2006; 16:375-80.

81. Virgini VS, Wijsman LW, Rodondi N, et al; PROSPER Study Group. Subclinical thyroid dysfunction and functional capacity among elderly. Thyroid 2014; 24:208-14

82. Lee JS, Buzková P, Fink HA, et al. Subclinical thyroid dysfunction and incident hip fracture in older adults. Arch Intern Med 2010; 170:1876-83.

83. Svare A, Nilsen TI, Asvold BO, et al. Does thyroid function influence fracture risk? Prospective data from the HUNT2 study, Norway. Eur Endocrinol 2013: 169:845-52.

84. Mainenti MR, Vigário PS, Teixeira PF, et al. Effect of levothyroxine replacement on exercise performance in subclinical hypothyroidism. J Endocrinol Invest 2009; 32:470-3.

85. Canpolat AG, Kav T, Sivri B, Yildiz BO. Effects of L-thyroxine on gastric motility and ghrelin in subclinical hypothyroidism: a prospective study. J Clin Endocrinol Metab 2013; 98:E1775-9.

86. Chung GE, Kim D, Kim W, et al. Non-alcoholic fatty liver disease across the spectrum of hypothyroidism. J Hepatol 2012; 57:150-6.

87. Cinemre H, Bilir C, Gokosmanoglu F, Bahcebasi T. Hematologic effects of levothyroxine in iron-deficient subclinical hypothyroid patients: a randomized, double-blind, controlled study. J Clin Endocrinol Metab 2009; 94:151-6.

88. Ravanbod M, Asadipooya K, Kalantarhormozi M, Nabipour I, Omrani GR Treatment of iron-deficiency anemia in patients with subclinica hypothyroidism. Am J Med 2013; 126:420-4.

89. Christ-Crain $M$, Meier C, Huber $P$, et al. Effect of restoration of euthyroidism on peripheral blood cells and erythropoietin in women with subclinical hypothyroidism. Hormones (Athens) 2003; 2:237-42.

90. Shin DH, Lee MJ, Lee HS, et al. Thyroid hormone replacement therapy attenuates the decline of renal function in chronic kidney disease patients with subclinical hypothyroidism. Thyroid 2013; 23:654-61.

91. Flynn RW, Bonellie SR, Jung RT, et al. Serum thyroid-stimulating hormone concentration and morbidity from cardiovascular disease and fractures in patients on long-term thyroxine therapy. J Clin Endocrinol Metab 2010; 95:186-93.

92. Teixeira PF, Reuters VS, Ferreira MM, et al. Treatment of subclinical hypothyroidism reduces atherogenic lipid levels in a placebo-controlled double-blind clinical trial. Horm Metab Res 2008; 40:50-5.

93. Glinoer D. What happens to the normal thyroid during pregnancy? Thyroid 1999; 9:631-5.

94. Soldin OP. Thyroid function testing in pregnancy and thyroid disease: trimester-specific reference intervals. Ther Drug Monit 2006; 28:8-11.

95. Stagnaro-Green A, Abalovich M, Alexander E, et al; American Thyroid Association Taskforce on Thyroid Disease During Pregnancy and Postpartum. Guidelines of the American Thyroid Association for the diagnosis and management of thyroid disease during pregnancy and postpartum. Thyroid 2011; 21:1081-125

96. De Groot L, Abalovich M, Alexander EK, et al. Management of thyroid dysfunction during pregnancy and postpartum: an Endocrine Society clinical practice guideline. J Clin Endocrinol Metab 2012; 97:2543-65.

97. Casey BM, Dashe JS, Wells CE, et al. Subclinical hypothyroidism and pregnancy outcomes. Obstet Gynecol 2005; 105:239-45.

98. Benhadi N, Wiersinga WM, Reitsma JB, Vrijkotte TG, Bonsel GJ. Higher maternal TSH levels in pregnancy are associated with increased risk for miscarriage, fetal or neonatal death. Eur J Endocrinol 2009; 160:985-91.

99. Allan WC, Haddow JE, Palomaki GE, et al. Maternal thyroid deficiency and pregnancy complications: implications for population screening. J Med Screen 2000; 7:127-30.

100. Negro R, Schwartz A, Gismondi R, et al. Increased pregnancy loss rate in thyroid antibody negative women with TSH levels between 2.5 and 5.0 in the first trimester of pregnancy. J Clin Endocrinol Metab 2010; 95:E44-8.

101. Liu H, Shan Z, Li C, et al. Maternal subclinical hypothyroidism, thyroid autoimmunity, and the risk of miscarriage: a prospective cohort study. Thyroid 2014; 24:1642-9.

102. Wilson KL, Casey BM, McIntire DD, Halvorson LM, Cunningham FG. Subclinical thyroid disease and the incidence of hypertension in pregnancy. Obstet Gynecol 2012; 119(2 Pt 1):315-20.

103. Leung AS, Millar LK, Koonings PP, Montoro M, Mestman JH. Perinatal outcome in hypothyroid pregnancies. Obstet Gynecol 1993; 81:349-53.

104. Reid SM, Middleton P, Cossich MC, Crowther CA, Bain E. Interventions for clinical and subclinical hypothyroidism pre-pregnancy and during pregnancy. Cochrane Database Syst Rev 2013; 5:CD007752.

105. Thangaratinam S, Tan A, Knox E, et al. Association between thyroid autoantibodies and miscarriage and preterm birth: meta-analysis of evidence. BMJ 2011; 342:d2616.

106. Cleary-Goldman J, Malone FD, Lambert-Messerlian G, et al. Maternal thyroid hypofunction and pregnancy outcome. Obstet Gynecol 2008; 112:85-92.

107. Saki F, Dabbaghmanesh MH, Ghaemi SZ, et al. Thyroid function in pregnancy and its influences on maternal and fetal outcomes. Int J Endocrinol Metab 2014; 12:e19378.

108. Smit BJ, Kok JH, Vulsma T, et al. Neurologic development of the newborn and young child in relation to maternal thyroid function. Acta Paediatr 2000; 89:291-5.

109. Li Y, Shan Z, Teng W, et al. Abnormalities of maternal thyroid function during pregnancy affect neuropsychological development of their children at 25-30 months. Clin Endocrinol (Oxf) 2010; 72:825-9.

110. Haddow JE, Palomaki GE, Allan WC, et al. Maternal thyroid deficiency during pregnancy and subsequent neuropsychological development of the child. N Engl J Med 1999; 341:549-55.

111. Ajmani SN, Aggarwal D, Bhatia P, et al. Prevalence of overt and subclinical thyroid dysfunction among pregnant women and its effect on maternal and fetal outcome. J Obstet Gynaecol India 2014; 64:105-10.

112. Lazarus JH, Bestwick JP, Channon S, et al. Antenatal thyroid screening and childhood cognitive function. N Engl J Med 2012; 366:493-501.

113. Negro R, Schwartz A, Gismondi R, et al. Universal screening versus case finding for detection and treatment of thyroid hormonal dysfunction during pregnancy. J Clin Endocrinol Metab 2010; 95:1699-707.

114. Kim CH, Ahn JW, Kang SP, et al. Effect of levothyroxine treatment on in vitro fertilization and pregnancy outcome in infertile women with subclinical hypothyroidism undergoing in vitro fertilization/ intracytoplasmic sperm injection. Fertil Steril 2011; 95:1650-4.

115. Wu T, Flowers JW, Tudiver F, Wilson JL, Punyasavatsut N. Subclinical thyroid disorders and cognitive performance among adolescents in the United States. BMC Pediatr 2006; 6:12.

116. Catli G, Abaci A, Büyükgebiz A, Bober E. Subclinical hypothyroidism in childhood and adolescense. J Pediatr Endocrinol Metab 2014; 27:1049-57.

117. Bona G, Prodam F, Monzani A. Subclinical hypothyroidism in children: natural history and when to treat. J Clin Res Pediatr Endocrinol 2013; 5 Suppl 1:23-8.

118. Gopalakrishnan S, Chugh PK, Chhillar M, et al. Goitrous autoimmune thyroiditis in a pediatric population: a longitudinal study. Pediatrics 2008; 122:e670-4.

119. Moore DC. Natural course of 'subclinical' hypothyroidism in childhood 
and adolescence. Arch Pediatr Adolesc Med 1996; 150:293-7.

120. Jaruratanasirikul S, Leethanaporn K, Khuntigij P, Sriplung H. The clinical course of Hashimoto's thryoiditis in children and adolescents: 6 years longitudinal follow-up. J Pediatr Endocrinol Metab 2001; 14:177-84.

121. Wasniewska M, Salerno M, Cassio A, et al. Prospective evaluation of the natural course of idiopathic subclinical hypothyroidism in childhood and adolescence. Eur J Endocrinol 2009; 160:417-21.

122. Lazar L, Frumkin RB-D, Battat E, et al. Natural history of thyroid function tests over 5 years in a large pediatric cohort. J Clin Endocrinol Metab 2009; 94:1678-82.

123. Radetti G, Gottardi E, Bona G, et al; Study Group for Thyroid Diseases of the Italian Society for Pediatric Endocrinology and Diabetes (SIEDP/ ISPED). The natural history of euthyroid Hashimoto's thyroiditis in children. J Pediatr 2006; 149:827-32.

124. Cerbone M, Bravaccio C, Capalbo D, et al. Linear growth and intellectual outcome in children with long-term idiopathic subclinical hypothyroidism. Eur J Endocrinol 2011; 164:591-7.

125. Di Mase R, Cerbone M, Improda N, et al. Bone health in children with long-term idiopathic subclinical hypothyroidism. Ital J Pediatr 2012; 38:56.

126. Ergür AT, Taner $Y, A$ Ata $E$, et al. Neurocognitive functions in children and adolescents with subclinical hypothyroidism. J Clin Res Pediatr Endocrinol 2012; 4:21-4.

127. Rapa A, Monzani A, Moia S, et al. Subclinical hypothyroidism in children and adolescents: a wide range of clinical, biochemical, and genetic factors involved. J Clin Endocrinol Metab 2009; 94:2414-20.

128. Chen H, Xi Q, Zhang H, et al. Investigation of thyroid function and blood pressure in school-aged subjects without overt thyroid disease. Endocrine 2012; 41:122-9.

129. Ittermann T, Thamm M, Wallaschofski H, Rettig R, Völzke H. Serum thyroid-stimulating hormone levels are associated with blood pressure in children and adolescents. J Clin Endocrinol Metab 2012; 97:828-34.

130. Cerbone M, Capalbo D, Wasniewska M, et al. Cardiovascular risk factors in children with long-standing untreated idiopathic subclinical hypothyroidism. J Clin Endocrinol Metab 2014; 99:2697-703.
131. Fallah R, Mirouliaei M, Bashardoost N, Partovee M. Frequency of subclinical hypothyroidism in 5- to 15 -year-old children with migraine headache. J Pediatr Endocrinol Metab 2012; 25:859-62.

132. Ekici B, Cebeci AN. The debate on the link between subclinical hypothyroidism and childhood migraine: is initial endocrinological evaluation necessary for children with migraine? Acta Neurol Belg 2015; 115:123-7.

133. Aijaz NJ, Flaherty EM, Preston T, et al. Neurocognitive function in children with compensated hypothyroidism: lack of short term effects on or off thyroxin. BMC Endocr Disord 2006; 6:2.

134. Wasniewska M, Corrias A, Aversa T, et al. Comparative evaluation of therapy with L-thyroxine versus no treatment in children with idiopathic and mild subclinical hypothyroidism. Horm Res Paediatr 2012; 77:376-81.

135. De Luca F, Corica D, Pitrolo E, Santucci S, Romeo M. Idiopathic and mild subclinical hypothyroidism in childhood: clinical management. Minerva Pediatr 2014; 66:63-8.

136. Cetinkaya E, Aslan A, Vidinlisan S, Ocal G. Height improvement by L-thyroxine treatment in subclinical hypothyroidism. Pediatr Int 2003; 45:534-7.

137. Eyal O, Blum S, Mueller R, Smith FO, Rose SR. Improved growth velocity during thyroid hormone therapy in children with Fanconi anemia and borderline thyroid function. Pediatr Blood Cancer 2008; 51:652-6.

138. Rother KI, Zimmerman D, Schwenk WF. Effect of thyroid hormone treatment on thyromegaly in children and adolescents with Hashimoto disease. J Pediatr 1994; 124:599-601.

139. Svensson J, Ericsson UB, Nilsson P, et al. Levothyroxine treatment reduces thyroid size in children and adolescents with chronic autoimmune thyroiditis. J Clin Endocrinol Metab 2006; 91:1729-34.

140. Jonklaas J, Bianco AC, Bauer AJ, et al; American Thyroid Association Task Force on Thyroid Hormone Replacement. Guidelines for the treatment of hypothyroidism: prepared by the American Thyroid Association Task Force on Thyroid Hormone Replacement. Thyroid 2014; 24:1670-751. 